\title{
Brazil's New Model of Dispute Settlement for Investment: Return to the Past or Alternative for the Future?
}

\author{
Geraldo Vidigal \\ University of Amsterdam, The Netherlands \\ g.vidigal@uva.nl
}

Beatriz Stevens

Permanent Mission of Brazil to the WTO and Other International Economic

Institutions, Geneva, Switzerland

stevens.beatriz@gmail.com

\begin{abstract}
This article assesses the contribution of Brazil's new bilateral treaties on investment, labelled Cooperation and Investment Facilitation Agreements (CIFAs), to the international legal framework for transnational investment. With its CIFAs, nine of which were concluded since 2015, Brazil offers an innovative model of International Investment Agreement (IIA) which does not contain investor-state dispute settlement (ISDS). Instead, CIFAs establish a system that combines dispute prevention mechanisms, creating institutions to ensure continued communication and foster cooperation, and state-tostate arbitration (inspired by dispute settlement provisions common in trade agreements and codified in the World Trade Organization's Dispute Settlement Understanding). Like recent initiatives put forward by India and the European Union, CIFAs aim not only to regulate bilateral relations but also to positively influence the current debates relating to the reform of the international investment regime. Whether they will become an alternative to the current ISDS-dominated framework will be determined by practice.
\end{abstract}

* This article was first presented at the Joint ASIL-ESIL-Max Planck Scholarship Workshop, 'The Future of Transatlantic Economic Governance in the Age of the BRICS', which took place in Heidelberg on 11-12 December 2015. We thank Marisa Goldstein and two anonymous reviewers for the careful reading and comments. Any views or opinions expressed in this articles are the authors' own, were written in their personal capacity, and do not represent the views of institutions or organizations they are or have been associated with.

(C) VIDIGAL AND STEVENS, 2018 | DOI:10.1163/22119000-12340100

This is an open access article distributed under the terms of the prevailing CC-BY-NC license at the time of publication. 


\section{Keywords}

Brazil - bilateral investment treaty - Cooperation and Investment Facilitation Agreements - investor-state dispute settlement - state-to-state dispute settlement

\section{Introduction}

The past decade has seen a growing debate regarding the extent to which international treaties should include provisions protecting transnational investment, and especially provisions allowing foreign investors to resort to international adjudication against states - referred to as investor-state dispute settlement (ISDS) provisions. The question entered the spotlight originally in connection with the negotiations of two major 'mega-regional' economic agreements. One was the Trans-Pacific Partnership (TPP), now replaced with the 11-party Comprehensive and Progressive Trans-Pacific Partnership (CPTPP), signed on 8 March 2018, ${ }^{1}$ and the other the Transatlantic Trade and Investment Partnership (TTIP), a proposed comprehensive economic agreement between the European Union (EU) and the United States. These two agreements, which originally would have covered countries that account for around $55 \%$ of global output, were not exclusively international investment agreements (IIAs), nor were they merely preferential trade agreements (PTAs) providing for reciprocal elimination of tariff barriers. They, and the megaregionals that succeeded them, embodied a much broader agenda of liberalization and integration, establishing a comprehensive regulation of economic matters and dealing with issues ranging from regulatory coherence to labour and environment standards to services and government procurement.

Much controversy has surrounded the inclusion in trade agreements of investment chapters which permit ISDS. Whereas the number of treaties featuring ISDS has increased exponentially over the past two decades, their popularity has been accompanied by growing controversy over the relinquishment by states of ultimate authority over the legal rights of foreign investors.

1 The original Trans-Pacific Partnership (TPP) was signed by twelve Members, including the United States. On 23 January 2017, the United States announced its withdrawal from the TPP. Most provisions of the TPP are now incorporated in the Comprehensive and Progressive Trans-Pacific Partnership (CPTPP), signed between all signatories to the TPP minus the United States on 8 March 2018. The text of the CPTPP is available via <www.mfat.govt .nz/en/trade/free-trade-agreements/free-trade-agreements-concluded-but-not-in-force/ cptpp/> accessed 1 June 2018. 
Additionally, with regard to their substantive provisions, IIAs are frequently seen as imposing many obligations on host states while establishing no duties for investors. This perception has generated a growing call for reform of the international investment regime.

This article focuses on the investment provisions contained in seven bilateral treaties recently signed by Brazil with other developing countries, in Africa and Latin America. The conclusion of these agreements, referred to as 'Cooperation and Investment Facilitation Agreements' (CIFAs), ${ }^{2}$ reflects efforts by Brazil to produce an alternative model of investment treaty, which purports to rebalance the set of rights and obligations between states and investors. Among the novelties of this model are the establishment of substantive obligations for investors, a focus on dispute prevention rather than adjudication, and the requirement that dispute settlement be initiated by the home state of the investor. We examine these elements of reform incorporated in CIFAs, comparing them to those proposals made by the EU in the context of TTIP negotiations and reflected in other recent economic agreements concluded by the EU, as well as to proposals made by India in its new Model Bilateral Investment Treaty (India Model BIT). We then discuss whether CIFAs offer an effective alternative for settling disputes regarding investment.

The article proceeds in six parts. Part 2 analyzes the broader framework within which the current debate regarding ISDS reform takes place. Part 3 examines the evolution of Brazil's position from rejection of the investment regime to the signature of CIFAs. Part 4 analyzes the content of CIFAs, discussing the capacity of state-to-state dispute settlement to ensure investment protection. Part 5 compares provisions in CIFAs to the proposals put forward by the EU and India for reform of the investment regime and discusses the potential for CIFA dispute settlement to be employed in practice, drawing lessons from the state-to-state dispute settlement regimes in the World Trade Organization (WTO) and in the United Nations Convention on the Law of the Sea (UNCLOS). Part 6 concludes.

2 In 2015, Brazil signed six treaties named 'Cooperation and Investment Facilitation Agreement', with Angola, Chile, Colombia, Malawi, Mexico, and Mozambique. The BrazilPeru 'Economic and Trade Expansion Agreement' concluded in 2016 is broader in scope, but features provisions regarding investment similar to those of CIFAs. It is referred to herein as Brazil-Peru CIFA. For the text of CIFAs, see <www.mdic.gov.br/comercio-exterior/ negociacoes-internacionais/218-negociacoes-internacionais-de-investimentos/1949-nii -acfi> accessed 28 March 2018. All translations are ours. 


\section{The Investment Regime: Structural Changes and Reform Proposals}

\subsection{The Development of the Investment Regime}

One of the most controversial issues in recent negotiations of economic agreements is whether to add to such treaties rules governing treatment of foreign investment and dispute settlement systems to enforce them. Investment protection, which in the 19th and early 20 th centuries was effected through intervention of the home state of the investor - often involving the use of force ${ }^{3}-$ evolved over the 2oth century towards peaceful negotiation and adjudication. Within this framework, the late 2oth century saw the development of ISDS, a powerful institutional arrangement aimed at preventing disputes regarding private investments from devolving into inter-state conflicts.

International investment law is unique in its architecture. Neither the substantive law on investment nor the procedural rules relating to dispute settlement are provided for in a single multilateral treaty. Whereas the large number of IIAs allows one to speak of a multilateral legal regime, ${ }^{4}$ this regime is grounded on a 'myriad of bilateral, regional, and sectoral investment treaties' ${ }^{5}$ IIAs provide for substantive obligations, but do not themselves establish an institutional structure. Instead, they usually direct investors to resort to ISDS against host states under pre-existing arbitration frameworks such as those provided by the World Bank's International Centre for Settlement of Investment Disputes (ICSID) and the United Nations Conference on International Trade Law (UNCITRAL).

Starting with a 1959 treaty between Germany and Pakistan, ISDS provisions were initially included in bilateral investment treaties (BITs) dealing exclusively with the rights of investors. Subsequently, beginning with the North American Free Trade Agreement (NAFTA), ${ }^{6}$ negotiators of preferential trade agreements started adding to the text of PTAs an investment chapter, which often permitted recourse to ISDS by nationals of one party holding investment in another party. Since the NAFTA, the network of IIAs and PTAs featuring ISDS grew exponentially over the 1990s, and kept on expanding in the 21st century. ${ }^{7}$

3 See Maria A Gwynn, 'South American Countries' Bilateral Investment Treaties: A Structuralist Perspective' (2015) 6 JIDS 97, 101-102.

4 Stephan W Schill, The Multilateralization of International Investment Law (CUP 2009); Zachary Douglas, The International Law of Investment Claims (CUP 2012).

5 Schill (n 4) 8 .

6 North American Free Trade Agreement (1993) 32 ILM 289, Chapter 11.

7 United Nations Conference on Trade and Development (UNCTAD), World Investment Report 2016 (United Nations 2016) 101. 
This expansion of investment law was accompanied by qualitative developments. Originally, BIT were signed mainly between developed, capitalexporting countries on the one hand, and developing, capital-importing countries on the other hand. Whereas the provisions in BITs formally applied equally to both parties, the distinct factual situations of the two parties made these treaties highly asymmetric in practice. The result was a regime often portrayed as 'neo-colonial,', 8 or as marked by the 'dynamics of imperialism', ${ }^{9}$ with the developing 'host' state accepting limitations on its conduct in order to induce investments originating from individuals and companies from the developed, capital-exporting country 'home' state.

By the late 2000s, this situation had changed. The development of a vast network of IIAs and PTAs with investment provisions, many of which involved more than one capital-exporting country, meant that developed countries could now foreseeably be targeted by ISDS complaints from investors from other capital-exporting countries. ${ }^{10}$ Coupled with the changing dynamics of capital flows, in which nationals of traditionally capital-importing countries increasingly hold investments in traditionally capital-exporting countries, ${ }^{11}$ this evolution resulted in changes to some assumptions about the role fulfilled by the different states within the investment regime.

In parallel, and particularly following the use of ISDS to challenge policies enacted by developed countries, ${ }^{12}$ a heightened awareness arose that ISDS could be employed to challenge not only outright expropriation but also policies enacted in the pursuit of non-economic objectives..$^{13}$ Concerns were thus raised that ISDS might be used to prevent the realization of a 'global' public interest, enshrined in other international conventions. ${ }^{14}$

\subsection{The Backlash Against Investment Arbitration}

In terms of substantive rules, IIAs establish a series of duties for states parties with regard to investors from the other party. Traditionally, IIAs were vague

8 Thomas Schultz and Cédric Dupont, 'Investment Arbitration: Promoting the Rule of Law or Over-Empowering Investors? A Quantitative Empirical Study' (2014) 25 EJIL 1147, 1151.

$9 \quad$ Kate Miles, The Origins of International Investment Law (CUP 2013) 386.

$10 \quad$ Schill (n 4$) 8$.

11 David Collins, The BRIC States and Outward Foreign Direct Investment (OUP 2013).

12 Among the most contentious recent cases are Vattenfall $A B$ and others $v$ Federal Republic of Germany, ICSID Case No ARB/12/12 (pending), and Philip Morris Asia Limited (Hong Kong) $v$ The Commonwealth of Australia, PCA Case No 2012-12, Award on Jurisdiction and Admissibility (17 December 2015) (finding that the claim was inadmissible).

13 Giorgio Sacerdoti and others (eds), General Interests of Host States in International Investment Law (CUP 2014).

14 Andreas Kulick, Global Public Interest in International Investment Law (CUP 2012). 
as regards the substantive obligations of states, referring to general concepts such as prohibition of 'denial of justice' and a duty to grant investors 'fair and equitable treatment'. The concrete content of these concepts was developed in a multitude of declarations, resolutions of international organizations, international judicial decisions, and (increasingly) arbitral awards. Crucially, most IIAs contain a most-favored-nation (MFN) clause establishing for both parties the obligation to grant to investors from the other party treatment no less favorable than that granted to investors of third states.

The combination of compulsory arbitration and ambiguous substantive provisions led investment tribunals to increasingly rely on previous arbitral decisions for guidance as regards legal interpretation of the scope and content of the obligations set forth in IIAs. Additionally, MFN clauses have been interpreted by a number of tribunals as permitting the 'import' into a BIT of a provision in another BIT, signed between the host state and a third state, as long as the investor finds this other provision to be 'more favorable' to its case than the relevant provision in the BIT endowing the tribunal with jurisdiction. ${ }^{15}$ Some tribunals have gone as far as to importing the very provision endowing them with jurisdiction. ${ }^{16}$ The number of claims has skyrocketed. Whereas between 1996 and 2000 investors started an average of 10 cases a year, this average increased to over 30 cases a year between 2006 and 2010, and almost 60 cases a year between 2011 and $2015 .{ }^{17}$

Here again, besides the absolute increase in the number of cases, a qualitative change has occurred, in the sense that developed countries, which traditionally did not host investments from their counterparts in BITs, found their own policies subject to challenge through ISDS. The two treaties that provided the basis for the largest number of investment arbitrations - the Energy Charter Treaty (ECT), with 97 cases, and NAFTA, with 77 cases - both involve more than one developed country, with the result that a number of arbitrations have been brought by investors against these traditionally capitalexporting countries. The most frequent target of ISDS under the ECT has been Spain, with $3^{1}$ cases started against it. This contrasts with seven cases started against Poland, six against Italy, Russia and Turkey, five against Hungary and

15 Emilio Agustín Maffezini v The Kingdom of Spain, ICSID Case No ARB/97/7, Decision of the Tribunal on Objections to Jurisdiction (25 January 2000).

16 Garanti Koza LLP v Turkmenistan, ICSID Case No ARB/11/20, Decision on Jurisdiction (3 July 2013).

17 UNCTAD (n 7$) 104$. 
Kazakhstan, and four against Bulgaria and Ukraine. ${ }^{18}$ Under NAFTA's ISDS provisions, between 1994 and 2014, 35 claims were brought against Canada, whereas 22 claims targeted Mexico, and 20 the United States. ${ }^{19}$

This wave of litigation has heightened a perception that there are structural imbalances in BITs and ISDS provides foreign investors with an unfair advantage, providing them with access to arbitral tribunals that prioritize their private interests over the public interests of the host state - and sometimes awarding large sums of money from public funds with no oversight by domestic courts. ${ }^{20}$ According to critics, proponents of ISDS consider it as 'simply a system of private ordering', a form of contractual dispute resolution needed to ensure balance in the bilateral relationship between investors and host states, Instead, they argue, the impact of ISDS is such that it should in fact be arranged as 'part of a comprehensive governance system meant to ensure justice and the rule of law in one aspect of international economic relations.' ${ }^{21}$ The view that investors were abusing the protection offered by ISDS led to a 'backlash'22 against it, and to attempts to find a better balance between preserving investors' rights and the state's right to regulate.

Between 2003 and 2010, resistance to investment arbitration was limited to states perceived as challengers of the post-Cold War global economic order. States such as Bolivia, Venezuela, Russia, and Ecuador not only voiced concerns with the system but followed up by withdrawing from treaties permitting ISDS. ${ }^{23}$ Subsequently, these states were joined by a number of developed

18 Other parties have between one and three cases started against them. Energy Charter Secretariat, 'Investment Dispute Cases Heatmap' <www.energycharter.org/what-we-do/ dispute-settlement/investment-dispute-settlement-cases/> accessed 10 August 2016.

19 Scott Sinclair, 'Democracy Under Challenge: Canada and Two Decades of NAFTA's InvestorState Dispute Settlement Mechanism' (Canadian Centre for Policy Alternatives 2015) 32 $<$ www.policyalternatives.ca/sites/default/files/uploads/publications/National\%2oOffice/ 2015/01/NAFTA_Chapter11_Investor_State_Disputes_2015.pdf> accessed 2 August 2016.

20 See with regard to Korea, Hi-Taek Shin and Liz (Kyo-Hwa) Chung, 'Korea's Experience with International Investment Agreements and Investor-State Dispute Settlement' (2015) 16 JWIT 952, 968. With regard to Latin America, Daniel de Andrade Levy and Rodrigo Moreira, 'ICSID in Latin America: Where Does Brazil Stand?' in Daniel de Andrade Levy, Ana Gerdau de Borja and Adriana Noemi Pucci (eds), Investment Protection in Brazil (Wolters Kluwer 2014) 22-26.

21 Frank J Garcia and others, 'Reforming the International Investment Regime: Lessons from International Trade Law' (2015) 18 JIEL 861, 874.

22 Michael Waibel and others (eds), The Backlash Against Investment Arbitration. Perceptions and Reality (Kluwer 2010).

23 Andrade Levy and Moreira (n 20). 
countries. In 2011, Australia announced its intention to no longer support any instrument that would 'confer greater legal rights on foreign businesses than those available to domestic businesses'. ${ }^{24}$ In 2014, Germany announced that it did not support ISDS in the proposed TTIP. ${ }^{25}$ In early 2015, Italy withdrew from the Energy Charter Treaty, ${ }^{26}$ while France and Germany jointly proposed to modify the ISDS provisions of the EU-Canada Comprehensive Economic and Trade Agreement (CETA) originally concluded in 2014. ${ }^{27}$

\subsection{Reform Proposals: Contests over the Function of ISDS}

These new developments challenge an overall narrative of expansion of the ISDS-dominated investment regime, in which ISDS was described as 'arguably the most astounding success in international law over the past decades.' ${ }^{28}$ It is possible to speak of a generation 'crossroads' 29 in the investment regime, with approximately $5^{\circ}$ countries currently undergoing revisions of their BIT templates and national investment policies, ${ }^{30}$ and some of them exploring entirely innovative structures for the regime.

Analyzing these developments, Thomas Schultz and Cédric Dupont have argued that, although investment arbitration was historically a 'neo-colonial'

24 Australian Government, Department of Foreign Affairs and Trade, 'Gillard Government Trade Policy Statement: Trading Our Way to More Jobs and Prosperity' (April 2011) 14. Australia subsequently revised this position. See Leon E Trakman, 'Investor-State Arbitration: Evaluating Australia's Evolving Position' (2014) 15 JWIT 152. Australia has also accepted the inclusion of ISDS in the CPTPP, which is inapplicable only between Australia and New Zealand.

25 Shawn Donnan and Stefan Wagstyl, 'Transatlantic Trade Talks Hit German Snag' (Financial Times, 14 March 2014).

26 Anna De Luca, 'Renewable Energy in the EU, the Energy Charter Treaty, and Italy's Withdrawal Therefrom' Bocconi Legal Studies Research Paper No $2657395<$ http://ssrn .com/abstract $=26573>$ accessed 23 January 2018.

27 France Diplomatie, 'Négociations commerciales - Déclaration commune de Sigmar Gabriel, Matthias Machnig et Matthias Fekl' (21 January 2015).

28 Thomas W Wälde, 'Improving the Mechanisms for Treaty Negotiation and Investment Disputes: Competition and Choice as the Path to Quality and Legitimacy' in Karl P Sauvant (ed), Yearbook on International Investment Law \& Policy 2008-2009 (OUP 2009) 505, 543.

29 Nicolás M Perrone, 'The International Investment Regime at a Crossroads: Should We Be Rethinking Foreign Investment Governance?' (Investment Treaty News, 19 February 2015) < www.iisd.org/itn/2015/o2/19/the-international-investment-regime-at-a-crossroad -should-we-be-rethinking-foreign-investment-governance/> accessed 2 February 2017.

30 United Nations Conference on Trade and Development (UNCTAD), International Investment Agreements Issue Note (February 2015) <http://unctad.org/en/Publications Library/webdiaepcb2015d1_en.pdf > accessed 2 February 2017. 
instrument employed to keep control over the economic resources of developed countries' nationals in newly independent countries, it has more recently evolved into an instrument of global governance that serves more broadly 'to strengthen the international rule of law', targeting both developing and developed countries alike. ${ }^{31}$ In a similar vein, Benedict Kingsbury and Stephan Schill have contended that ISDS is 'developing into a form of global governance'. ${ }^{32}$ Armin von Bogdandy and Ingo Venzke include investment arbitral tribunals among the examples of international adjudicators increasingly going beyond mere settlement of bilateral disputes and 'exercis[ing] a form of international public authority'. ${ }^{33}$

This perception of the functions of ISDS is, of course, an academic construct, and is not necessarily shared by investment tribunals themselves. Instead, many of these tribunals seem to ascribe to a narrower view under which ISDS is simply a means of settling a dispute between two parties. ${ }^{34}$ Pursuant to this view, the fact that one of the parties to a dispute happens to be a state does not change its essentially private nature. As a consequence, the perceived aim of dispute resolution becomes to give effect to the agreement between the parties, and to enforce commitments rather than to actively take into account public interest considerations. In fact, from this perspective, enforcing commitments is the realization of public interest, in the sense that it guarantees property rights and makes promises credible, allowing private actors to allocate resources in the most efficient way. ${ }^{35}$

Despite resistance from many corners, including a number of practitioners in investment arbitration, ${ }^{36}$ this change of perspective regarding the role of ISDS has now been accepted by a number of governments. It is partly at the

31 Schultz and Dupont (n 8).

32 Benedict Kingsbury and Stephan W Schill, 'Investor-State Arbitration as Governance: Fair and Equitable Treatment, Proportionality and the Emerging Global Administrative Law' (2009) NYU School of Law, Public Law Research Paper No. 09-4.

33 Armin von Bogdandy and Ingo Venzke, In Whose Name? A Public Law Theory of International Adjudication (OUP 2014).

34 See Zachary Douglas, 'The Hybrid Foundations of Investment Treaty Arbitration' (2003) 74 BYIL 151.

35 See Ronald Coase, 'The Problem of Social Cost' (1960) 3 Journal of Law and Economics 1.

36 See Charles N Brower and Sarah Melikian, 'We Have Met the Enemy and He Is Us! Is the Industrialized North Going South on Investor-State Arbitration?' (2015) 31 Arb Intl 19; Catherine M Amirfar, ‘Treaty Arbitration: Is The Playing Field Level and Who Decides Whether It Is Anyway?' in Albert Jan van den Berg (ed), Legitimacy: Myths, Realities, Challenges, ICCA Congress Series No 18 (Miami 2014) (Kluwer Law International 2015) $755^{-775}$. 
root of the reform initiatives aimed at transforming the ISDS system, revisiting some of the fundamental provisions found in IIAs and examining alternatives in the area of international investment governance. Besides suggestions from academics, ${ }^{37}$ some governmental proposals and model treaties have attempted to address concerns regarding imbalances found in the current ISDS system. Initiatives aimed at giving shape to an investment regime in which public concerns are given more weight include, most recently, the proposal of the EU to the United States of an Investment chapter in the planned TTIP, published on 12 November 2015 (TTIP EU Proposal), 38 and the India Model BIT, released in January 2016. ${ }^{39}$

Among developed economies, the EU has gone the furthest in its attempt to reform the investment regime. The EU's efforts began with CETA, which was originally concluded between Canada and the EU in August 2014 and featured traditional ISDS provisions. At the request of the EU, it was renegotiated in 2016, with significant changes to the investment chapter. The revised text, discussed below, features a novel system providing for the establishment of a permanent Tribunal and an Appellate Tribunal. ${ }^{40}$

The modifications to CETA reflect the EU's response to internal criticism of ISDS and embody a proposal for an alternative dispute settlement regime. This alternative was integrated in the EU-Vietnam Free Trade Agreement ${ }^{41}$ and is also being pursued in the context of TTIP negotiations (in the latter case, with seemingly less chances of success). Its central aim is to depart from the ad hoc ISDS adjudication largely found in BITs to date and create a permanent investment adjudication system, including an appeals mechanism similar to that found in the WTO. In announcing its Proposal for a Council Decision on CETA, the European Commission described this 'new investment

ibid; Karl Sauvant and Federico Ortino, Improving the International Investment Law and Policy Regimes: Options for the Future (Ministry of Foreign Affairs of Finland 2013).

38 European Union's proposal for Investment Protection and Resolution of Investment Disputes for the Transatlantic Trade and Investment Partnership, Trade in Services, Investment and E-Commerce, Chapter II - Investment, 12 November $2015<$ http://trade .ec.europa.eu/doclib/docs/2015/november/tradoc_153955.pdf> accessed 6 March 2016.

39 See 'Model Text for the Indian Bilateral Investment Treaty' <http://investmentpolicyhub .unctad.org/Download/TreatyFile/356o> accessed 26 March 2018.

40 European Commission, 'EU and Canada Agree on a New Approach on Investment in Trade Agreement' Press Release, Brussels (29 February 2016).

41 'Standing Tribunal included in European Union-Vietnam FTA' (Investment Treaty News, 29 February 2016). For the text of EU-Vietnam Investment chapter see <http://trade .ec.europa.eu/doclib/docs/2016/february/tradoc_154210.pdf>accessed 31 January 2018. 
court system' as an important first step 'towards the EU's ultimate goal of a global investment court. ${ }^{42}$

Both the EU's proposal and India's Model BIT, discussed below, aim to reform ISDS by making it more judicialized, foreseeing the establishment of a standing adjudicatory body as well as avenues for pursuing appellate review in ISDS disputes. Brazil's CIFAs focus on a less judicialized alternative. With these agreements Brazil, a large developing economy (and one of the few states that remained outside the ISDS-dominated investment legal regime) appears to pursue a different route from the one set out in the EU's TTIP proposal and in the India Model BIT.

\section{Brazil's Alternative: CIFAs, Dispute Prevention, and Dispute Settlement}

\subsection{The Evolution of Brazil's Policy Towards Investment Agreements}

Contrary to the majority of its Latin American neighbors, Brazil never ratified any international investment agreement containing ISDS clauses (between 1994 and 1999, it signed a total of 14 BITs, but never ratified them) and never adhered to the ICSID Convention..$^{43}$ The dispute settlement provisions in its two bilateral treaties on investment in force, both signed before the treaty between Germany and Pakistan that inaugurated ISDS, are inter-state and non-compulsory. ${ }^{44}$

42 European Commission, 'European Commission Proposes Signature and Conclusion of EU-Canada Trade Deal' Press Release, Brussels (5 July 2016) <http://europa.eu/rapid/ press-release_IP-16-2371_en.htm> accessed 31 January 2018.

43 Convention on the Settlement of Investment Disputes Between States and Nationals of Other States (signed 18 March 1965) 575 UNTS 159. For the experience of Latin American states, see Gwynn (n 3 ).

44 Brazil ratified two earlier pre-ISDS investment treaties, one with Paraguay (Tratado Geral de Comércio e Investimentos entre a República dos Estados Unidos do Brasil e a República do Paraguai (signed 27 October 1956, entered into force 6 September 1957)) and one with the United States (Investment Guaranty Agreement Between the Government of the United States of America and the Government of the United States of Brazil (1965) 4 ILM 296). Whereas no third-party dispute settlement exists under the Brazil-Paraguay treaty, the Brazil-US treaty permits inter-state arbitration, following exhaustion of local remedies (Article VI:4). See 'Arbitration is to be carried out pursuant to the General Treaty of InterAmerican Arbitration' (1929) 2 AJIL Supplement Official Documents 82. The General Treaty requires parties to submit their disputes 'of a juridical character' to arbitration, 
Brazil's reasons for not adhering to the ISDS-dominated investment regime are twofold. First, there were doubts regarding constitutional barriers to the submission of the Brazilian state to investment arbitration..$^{45}$ Second, the country was able to maintain its attractiveness to investment by means that did not bind it to ISDS. Indeed, Brazil consistently ranks among the top 10 recipients of foreign direct investment (FDI) worldwide. Even in the crisis years of 2014 and 2015, Brazil ranked 4th worldwide among FDI recipients. ${ }^{46}$ At least for a country with the characteristics of Brazil, it appears that IIAs are not determinant for attracting FDI.

Brazil's absence from the international investment law regime does not mean foreign investors are not safeguarded in the country. Especially since the enactment of an arbitration law in 1996, contractual arbitration has increasingly been used as a means of dispute resolution in state contracts. A number of decisions of the Brazilian higher courts have confirmed the legality of arbitral clauses in state contracts and the enforceability of arbitral awards against the state. ${ }^{47}$ As regards the international investment regime, however, Brazil's position has remained that of an attentive bystander.

This, however, changed significantly in 2015, when Brazil signed six CIFAs with Mozambique, Angola, Malawi, Mexico, Colombia, and Chile. In 2016, Brazil signed a broader agreement with Peru - the 'Economic and Trade Expansion Agreement' - featuring similar provisions with regard to investment. Brazil has described the goal of CIFAs as 'to create incentives for reciprocal investment through intergovernmental dialogue mechanisms', with the aim of establishing rights and obligations for investors and states alike and to provide an alternative institutional model for prevention and settlement of disputes.

This shift in policy had its roots in factual developments. As its economy evolved over the past 25 years, Brazil multiplied its outward FDI, which grew approximately twentyfold between 1991-1995 and 2006-2010. ${ }^{48}$ Brazil

but does not provide for any fall-back mechanism in case the parties fail to appoint arbitrators.

Only in December 2001 did Brazil's Supreme Court affirm with finality the constitutionality of Brazil's 1996 Arbitration Law (Agravo Regimental na sentença estrangeira No 5.206-7 (Kingdom of Spain) [2001]).

46 UNCTAD (n 7$) 5$.

47 Daniel M C Barbosa and Pedro Martini, 'Two Sides of the Same Coin: To What Extent Is Arbitration with the Brazilian Administration Similar to Investment-Treaty Arbitration?' in Andrade Levy, Gerdau de Borja and Pucci (n 20) 37-59.

48 UNCTAD $(\mathrm{n} 7)$. Annex, Tables - FDI Outflows (from an average of USD 685.9 million per year in the years 1991-1995 to an average of USD 13,540.4 million per year in 2006-2010. Outflows have since declined sharply, however, and the average outflow for 2011-2015 was of USD 1,976.5 million - still the triple of 1991-1995 levels). 
increasingly became a source of FDI, directed especially to countries in South America and Africa. This reignited the public debate concerning the importance of providing a framework to regulate the relationship between foreign investors and government. ${ }^{49}$

Overcoming Brazil's traditional resistance to IIAs, CIFAs create a new regime for the protection of FDI, excluding ISDS and instead setting out a hybrid system of dispute prevention mechanisms and state-to-state arbitration. CIFAs establish a legal framework for the home government of investors to defend the interests of its nationals, negotiating directly with, or starting arbitral proceedings against, the government of the host state. Arbitration is explicitly aimed at ensuring compliance rather than providing investors with compensation for breach.

Among the distinctive features of CIFAs when compared to other IIAs is the attempt to establish substantive obligations for investors, institutionalizing efforts to ensure corporate social responsibility. CIFAs set forth a general "best efforts" obligation, addressed at investors, to contribute to the extent possible with the 'sustainable development of the Host Country by adopting a high degree of measures of corporate social responsibility'. ${ }^{50}$ Some CIFAs define such practices, along the lines of directives established by the Organization for Economic Co-operation and Development (OECD), ${ }^{51}$ establishing general guidelines and standards for investment decisions, ranging from protecting the environment and human rights to respecting local political processes to 'abstaining from seeking or accepting exemptions not established in the laws of the host state. 52

The biggest difference between CIFAs and most contemporary IIAs, however, is that CIFAs do not feature ISDS. Rather, they establish a number of institutions and procedures aimed at preventing differences from escalating into litigious disputes.

\section{2}

\section{CIFA Dispute Prevention and Dispute Settlement}

\subsubsection{Dispute Prevention: Focal Points and Joint Committees}

A number of CIFA provisions concern the prevention of disputes, aiming to avoid recourse to litigation. For this purpose, CIFAs provide for the

\footnotetext{
49 See the contributions in Andrade Levy, Gerdau de Borja and Pucci (n 20).

50 Brazil-Angola Cooperation and Facilitation Agreement, art 10.

51 OECD Guidelines for Multinational Enterprises <http://mneguidelines.oecd.org/text> accessed 6 March 2016.

52 Brazil-Angola CIFA, Annex II; Brazil-Mozambique CIFA, Annex II; Brazil-Malawi CIFA, art 9(2); Brazil-Chile CIFA, art 15(2).
} 
establishment of two different institutions: one 'Focal Point' or 'ombudsman' for each party, ${ }^{53}$ and one Joint Committee. Focal Points are domestic governmental institutions of the parties, whereas the Joint Committee is a political decision-making treaty organ, composed of both parties to the treaty acting jointly and responsible for administering the relevant agreement. ${ }^{54}$

Focal Points are governmental instruments that must act to ensure proper implementation of CIFAs, serving as points of first contact for foreign investors in the host state. They give investors support and hear their complaints, with the aim of preventing the emergence of formal disputes between investors and host states. Contact points of the parties to a CIFA must also be in touch with each other and apply directives issued by the Joint Committee. ${ }^{55}$

The creation of CIFA focal points is inspired by the positive experience of South Korea with an investment ombudsman. South Korea's Office of the Foreign Investment Ombudsman (OFIO) provides post-investment services for foreign investors and on-site consultations regarding issues of finance, taxation, accounting, intellectual property rights, construction issues and labour issues. OFIO hears grievances brought to it by foreign investors, and is empowered to contact ministers and high-level governmental authorities directly in order to solve grievances, not only dealing with specific issues but also proposing systemic improvements and legal changes. OFIO has received on average 400 cases a year since its creation in 1999. The resolution rate, initially at $25 \%$, now consistently reaches over $90 \%$ (2007-2011 data) ${ }^{56}$ OFIO is widely recognized as the entity responsible for the virtual absence of ISDS claims filed against Korea (only one, for around go treaties in force featuring ISDS). ${ }^{57}$

One salient aspect that distinguishes CIFA dispute prevention is that not only investors but also governments can engage with the Focal Points when disagreements arise over an investment relationship. By allowing for

53 In Brazil's case, the focal point is attached to CAMEX (Câmara de Comércio Exterior), an inter-ministerial governmental body entrusted with formulating and implementing international trade policy.

54 Fabio Morosini and Michelle Ratton Sanchez Badin, 'The Brazilian Agreement on Cooperation and Facilitation of Investments: A New Formula for International Investment Agreements?' (Investment Treaty News, 4 August 2014).

55 Brazil-Mozambique CIFA, art 5; Brazil-Angola CIFA, art 5; Brazil-Malawi CIFA, art 4; Brazil-Colombia CIFA, art 17; Brazil-Mexico CIFA, art 15; Brazil-Chile CIFA, art 19.

56 Françoise Nicolas, Stephen Thomsen and Mi-Hyun Bang, 'Lessons from Investment Policy Reform in Korea' OECD Working Papers on International Investment 2013/o2 (OECD 2013) 24-25.

57 ibid. 
government participation, CIFAs also provide host governments with a forum to express grievances against investor behavior. This option is in fact one of the elements currently being debated in the international investment regime reform, given that corruption practices and environmental damage may be left unpunished as the result of a state's inability to sue investors under IIAs. ${ }^{58}$

In order to avoid resort to adjudication when Focal Points are unsuccessful, CIFAs also require that 'questions of specific interest to an investor' be referred to the Joint Committee prior to the initiation of disputes. The Joint Committee must examine the dispute; hear the parties, as well as the investor and the governmental and non-governmental entities involved in the dispute; and issue a public report, which describes the dispute and the positions of the parties. ${ }^{59}$ Joint Committees, also seen in other international agreements, ${ }^{60}$ play an important institutional role in CIFAs. They provide a further avenue for resolving potential conflicts without recourse to litigation.

The large role entrusted to Joint Committees and Focal Points is evidence of the perspective that underlies CIFAs: providing institutions and instruments for inter-state cooperation, bringing an element of diplomacy to the investment protection regime.

\subsubsection{Dispute Settlement: 'African' versus 'Latin American' Treaties}

In case the parties are unable to resolve their differences through consultations mediated by the Joint Committee, a distinction appears between two 'types' of CIFAs. The three 'African' CIFAs make dispute settlement fully optional, merely allowing for state-to-state arbitration if both states parties agree thereto. By contrast, the four 'Latin American' CIFAs contain arbitral clauses, empowering either party to unilaterally initiate arbitration proceedings against the other party.

Thus, the Brazil-Angola CIFA establishes that, in case the dispute cannot be settled through negotiations or by a recommendation from the Joint Committee, the parties 'may have recourse to state-to-state arbitration mechanisms', ${ }^{61}$

$5^{8}$ Nathalie Bernasconi-Osterwalder and Martin Dietrich Brauch, 'Comparative Commentary to Brazil's Cooperation and Investment Facilitation Agreements (CIFAs) with Mozambique, Angola, Mexico, and Malawi' (September 2015) < www.iisd.org/sites/default/ files/publications/commentary-brazil-cifas-acfis-mozambique-angola-mexico-malawi .pdf> visited 14 February 2018> accessed 14 February 2018.

59 Brazil-Mozambique CIFA, art 15; Brazil-Angola CIFA, art 15; Brazil-Malawi CIFA, art 13; Brazil-Colombia CIFA, art 22; Brazil-Mexico CIFA, art 18; Brazil-Chile CIFA, art 24.

6o United States-Korea FTA, art 22.2; Australia-New Zealand-ASEAN FTA of 2009, ch 16.

61 Brazil-Angola CIFA, art 15(6). 
which means that arbitration would require a new agreement between the two states parties. Under the Brazil-Mozambique and Brazil-Malawi CIFAs, disputes not settled by agreement may be submitted to arbitration 'whenever deemed convenient by the parties. ${ }^{62}$ These treaties refer to state-to-state arbitration mechanisms 'to be established by the Joint Committee'. Although the wording of the provision does not appear to preclude the subsequent establishment of mechanisms in which arbitration is compulsory, this would seem to require a new agreement between the parties. ${ }^{63}$

By contrast, the 'Latin American' CIFAs feature enforeable dispute settlement provisions, and establish a two-stage process. At the first stage, the Joint Committee must be formally seized with the dispute; it is given a 6o-day period of time to issue a report on the matter. If this does not solve the dispute, either party may unilaterally request arbitration, conducted (in the absence of agreement between the parties to take the dispute to an institutional mechanism) before an ad hoc arbitral tribunal.

Importantly, a fall-back mechanism is available to prevent parties from frustrating the dispute settlement procedure by failing to appoint arbitrators. In case the parties fail to appoint members to the tribunal or in case the partyappointed arbitrators fail to jointly appoint a chair within specified deadlines, these appointments are to be made by an international institution. In the Brazil-Mexico and Brazil-Peru CIFAs, the appointing authority is the President of the International Court of Justice (ICJ). ${ }^{64}$ In the Brazil-Colombia and BrazilChile CIFAs, it is the Secretary-General of the Permanent Court of Arbitration (PCA). ${ }^{65}$

62 Brazil-Mozambique CIFA, art 15(6); Brazil-Malawi CIFA, art 13(6).

63 Bernasconi-Osterwalder and Brauch $\left(\mathrm{n}_{5}{ }^{8}\right) 11$ make the point that the Brazil-Angola CIFA contains a most-favoured-nation (MFN) provision in Article 11(7), requiring MFN treatment with regard to 'access to courts of justice and administrative agencies, or to the defence of the rights of such investors'. This provision, they argue, could be interpreted as allowing investors access to ISDS in case one of the parties grants this access to investors in third states.

64 Brazil-Mexico CIFA, art 14(4)-14(6); Brazil-Peru CIFA, art 2.21(7). In case the President is a national of one of the parties or is otherwise impeded, the Vice-President is to make the appointments. In case of impediment of the Vice-President, the most senior ICJ judge not impeded is to make the appointments.

65 Brazil-Colombia CIFA, art 23(7); Brazil-Chile CIFA, Annex I, art 4(4). In case of impediment, the most ancient unimpeded member of the PCA is to make the appointments. 


\section{CIFA's Compliance-Oriented Adjudication, Restitution and Compensation}

\subsection{The WTO-Inspired CIFA Adjudication Provisions}

The CIFAs that do establish compulsory arbitration mechanisms appear to draw heavily on the language of the WTO Dispute Settlement Understanding (DSU). Article 3 of Annex I of the Brazil-Chile CIFA, which sets out the terms of reference of arbitral tribunals, describes them as:

To examine, in an objective manner and in light of the relevant provisions of this agreement, the matter referred in the request for establishment of the arbitral tribunal, and to make findings of fact and law, making a motivated determination of whether or not the measure in question is in conformity with the Agreement.

This language echoes Article 7.1 of the DSU, which establishes as the standard terms of reference for WTO panels ' $\mathrm{t}$ ] $\mathrm{o}$ examine, in the light of the relevant provisions ..., the matter referred' to WTO adjudication. Article 11 DSU adds that that 'a panel should make an objective assessment of the matter before it, including an objective assessment of the facts of the case and the applicability of and conformity with the relevant covered agreements'. Finally, Article 12.7 DSU provides that 'the report of panel shall set out the findings of fact, the applicability of the relevant provisions and the basic rationale behind any findings and recommendations that it makes'.

Besides drawing language from its text, CIFAs share with WTO adjudication the purpose, declared in Article 3.7 DSU, of re-establishing compliance following a finding of inconsistency. ${ }^{66}$ The Brazil-Mexico and Brazil-Peru CIFAs state this goal explicitly, whereas the Brazil-Chile and Brazil-Colombia CIFAs use slightly different wording, providing that the goal of arbitration is to determine compliance with CIFA rules. ${ }^{67}$ The Brazil-Mexico CIFA derives from this goal an inability of arbitrators to award damages:

The goal of arbitration is to put in conformity with this agreement any measure declared in the arbitral award not to conform to it. The parties

66 In the relevant part, DSU, art 3.7 reads: 'the first objective of the dispute settlement mechanism is usually to secure the withdrawal of the measures concerned if these are found to be inconsistent with the provisions of any of the covered agreements'.

67 Brazil-Chile CIFA, Annex I, art 3; Brazil-Colombia CIFA, art 23.2; Brazil-Mexico CIFA, art 19.2; Brazil-Peru CIFA, art 2.21(2). 
may notwithstanding agree that the arbitrators consider the existence of damages caused by the challenged measure and establish in the award compensation for these damages. If the award does determine monetary compensation, the party that receives this compensation must transfer it to the owners of the rights over the investment in question, after deducting the costs of litigation, following the domestic procedure of each party. 68

This wording contrasts two distinct and, it would seem, alternative remedies available following a finding of breach. One is a formal declaration of the obligation to put into conformity with the agreement a measure found to be CIFAinconsistent. The other, subject to the agreement of the (states) parties, is the possibility of an award requiring payment of compensation for damages. The same result arises from the provision in the Brazil-Colombia CIFA precluding arbitral tribunals from awarding an indemnity for damages unless the parties sign a specific agreement to this effect. ${ }^{69}$

These provisions reverse the traditional focus of investment tribunals on compensation awards. Compensation is perceived as useful in that it allows tribunals not to intervene in sovereign decisions, providing remedies to investors without requiring states to modify their conduct. From the viewpoint of a good-faith government, however, a monetary award means that an investor will leave the country with taxpayers' money and cease performing its function of generating economic value. ${ }^{70}$ Depending on the amount of the award and on the government's budget, paying compensation may require significant reductions in public investments and governmental programs.

Additionally, the stated aim of not interfering with sovereignty does not take into account that, when amounts are high enough, monetary remedies do constitute a significant deterrent to conduct. Even if tribunals may recognize the right of the host state to 'exercise ... normal regulatory power in the pursuance of a public interest, ${ }^{71}$ the mere possibility of having to deal with potentially costly ISDS claims could lead a government to refrain from

68 Brazil-Mexico CIFA, art 19.2.

69 Brazil-Colombia CIFA, art 23(14).

70 Under the Salini criteria, this would be the 'contribution to the development of the host State of the investment' (Salini et al v Morocco, ICSID Case No ARB/oo/4, Decision on Jurisdiction (31 July 2001) para 52). Given that developed countries can now expect to be respondents as well, 'generate economic value' appears more appropriate.

71 Philip Morris Brands Sàrl, Philip Morris Products SA and Abal Hermanos SA v Oriental Republic of Uruguay, ICSID Case No ARB/10/7, Award (8 July 2016) para 423. 
adopting important policies because of their consequential impacts on foreign investors - an effect commonly referred to as 'regulatory chill: ${ }^{72}$

In this regard, CIFAs appear to assume that governments would in principle prefer investors to stay and aim to facilitate mutually satisfactory solutions that enable them to do so, rather than compensate aggrieved investors. While only the Brazil-Colombia and Brazil-Mexico CIFAs are explicit regarding the limitation on compensation awards, remedy provisions in the other two Latin American CIFAs appear to share this assumption. The Brazil-Peru CIFA declares that the objective of arbitration is to re-establish conformity with the rules of the relevant agreement, ${ }^{73}$ while the Brazil-Chile CIFA provides (in wording that also appear in the Brazil-Colombia CIFA) that the goal of arbitration is to determine the conformity of measures taken by one of the parties with the Agreement, and that parties must 'comply with [the award] without delay'. ${ }^{74}$ Article 9 of the Brazil-Chile CIFA goes on to state that the respondent party must 'comply with the award immediately, or, in case this is not possible, within a reasonable period of time' - another term drawn from WTO law. ${ }^{75}$

The Brazil-Chile ${ }^{76}$ and Brazil-Colombia ${ }^{77}$ CIFAs empower tribunals solely to establish whether or not a challenged conduct violates CIFA rules - and not to derive any consequences from this finding. The result is that, in arbitrations under these CIFAs, the parties are under the obligation to 'comply' with an award which, pursuant to a purely textual interpretation, cannot prescribe any specific conduct but only determine whether the challenged conduct was lawful.

\subsection{Determining Remedies in CIFA Arbitration}

Given the vagueness of remedy provisions in CIFAs, tribunals will be required to determine the extent of their power to award remedies. Tribunals could specifically determine, in the operative part of the awards, what the compliance

72 See Christine Côté, A Chilling Effect? The Impact of International Investment Agreements on National Regulatory Autonomy in the Areas of Health, Safety and the Environment (PhD thesis, London School of Economics 2014).

73 Brazil-Peru CIFA, art 2.21(2).

74 Brazil-Chile CIFA, Annex I, arts 3 and 7.4. The same provisions exist in the BrazilColombia CIFA, arts 23.2 and 23.12 .

75 DSU, art 21.3 provides, in the relevant part: 'If it is impracticable to comply immediately with the recommendations and rulings, the Member concerned shall have a reasonable period of time in which to do so.'

76 Brazil-Chile CIFA, Annex I, arts 3 and 7.3, however, appears to open the door for an award to contain 'other elements that the tribunal deems fitting'.

77 Brazil-Colombia CIFA, art 23.2. 
obligation entails. They could rely on the conclusion of the Permanent Court of International Justice (PCIJ) and International Court of Justice (ICJ), that an international tribunal's jurisdiction over a dispute includes the power to award the corresponding remedies and lay down the conditions for the re-establishment of the treaty rights affected. ${ }^{78}$

In this case, the question would be the extent to which these conditions involve the payment of reparation for injury caused by the conduct the tribunal found to be unlawful. In Chorzów Factory, the PCIJ stated:

It is a principle of international law that the breach of an engagement involves an obligation to make reparation in an adequate form. Reparation therefore is the indispensable complement of a failure to apply a convention and there is no necessity for this to be stated in the convention itself. ${ }^{79}$

Following the PCIJ, a number of other international adjudicators have inferred from their adjudicatory functions the power to award monetary remedies. ${ }^{80} \mathrm{As}$ a matter of general international law, this view is now reflected in the rules codified in the International Law Commission's Articles on State Responsibility, which recognize as core legal consequences of any violation the obligations of cessation and reparation. The former requires a state to cease all unlawful conduct following a determination that it is unlawful, ${ }^{81}$ whereas the latter requires the wrongdoer to reverse, or compensate, any harmful effects caused

78 Factory at Chorzów (Claim for Indemnity) (Merits) (Germany v Poland) [1928] PCIJ Ser A No 17, 29; LaGrand Case (Germany v United States of America), ICJ Reports 2001, 466, 485. See also M/V “SAIGA" (No. 2) (Saint Vincent and the Grenadines v Guinea), Judgment (1999) 38 ILM 1323, 1357.

79 Factoryat Chorzów (Claim for Indemnity) (Jurisdiction) (Germanyv Poland) [1927] PCIJ Ser A No 9, 20-21.

8o $\quad$ Aloeboetoe $v$ Suriname (Reparations and Costs) (1993) IACHR Series C No 15 para 43; CJEU, Case C-6/9o, Francovich [1991] ECR I-5357 paras 33-36; Papamichalopoulos and Others v Greece (Article 5o), App No 14556/89, ECHR Series A, No 330-B [1995], para 34; Eritrea-Ethiopia Claims Commission, Final Award - Ethiopia's Damages Claims (2009) 26 RIAA 631, 633 .

81 In Navigational and Related Rights, the ICJ stated: 'when the Court has found that the conduct of a State is of a wrongful nature, and in the event that this conduct persists on the date of the judgment, the State concerned is obliged to cease it immediately ... the obligation incumbent on the State concerned to cease such conduct derives by operation of law from the very fact that the Court establishes the existence of a violation of a continuing character' (Navigational and Related Rights (Costa Rica v Nicaragua), Judgment (13 July 2009) ICJ Reports 2009, 21, 267). 
to others by its wrongful conduct. Article 31(1) of the Articles codifies the duty of reparation, providing that a wrongdoing state has 'an obligation to make full reparation for the injury caused by the internationally wrongful act'. ${ }^{2}$

On the other hand, the fact that CIFAs draw so heavily on WTO law could lead tribunals to exercise restraint with regard to performance remedies and issue solely WTO-inspired ruling requiring that party found in breach 'bring the measure into conformity'. ${ }^{83}$ In this case, the question concerns the extent to which the inspiration drawn from the WTO means that a party found to have violated its obligations under a CIFA may provide redress for its past conduct simply by changing this conduct for the future, i.e. prospectively, ceasing, revoking or modifying for the future (ex nunc) the measure found to contravene its obligations.

In WTO law, the notion that WTO remedies are 'prospective' was initially a contentious one. The prevailing interpretation, based on the practice of a vast majority of GATT panels, is that any injury caused by the wrongful measure can remain uncompensated, without any legal consequences for the Member found in violation of its obligations. ${ }^{84}$ The Appellate Body has described the remedies provided for in the WTO Agreements as 'prospective in nature. ${ }^{85}$ On the other hand, Article 3.7 of the DSU refers to the 'withdrawal' of measures found to be inconsistent with WTO rules, which - in conjunction with the rules of general international law on reparation - could provide a basis for the view that 'bring[ing] the measure into conformity' requires both revoking the measure and reversing its effects.

Some early WTO panels considered that, in at least some cases, remedies provisions should be interpreted as requiring Members to reverse the effects of their WTO-inconsistent conduct. ${ }^{86}$ However, the Appellate Body has

82 International Law Commission, 'Draft Articles on Responsibility of States for Internationally Wrongful Acts, with Commentaries' [2001] ILC YB, II.2, 1, 87, 91.

83 DSU, art 19.1 provides that an adjudicator that 'concludes that a measure is inconsistent with a covered agreement ... shall recommend that the Member concerned bring the measure into conformity with that agreement' (footnotes omitted). The DSU also allows panels and the Appellate Body to make suggestions regarding how compliance may be achieved - a power rarely used.

84 For an analysis of GATT and WTO jurisprudence on the matter, see Geraldo Vidigal, 'Re-Assessing WTO Remedies: The Prospective and the Retrospective' (2013) 16 JIEL 505.

85 WTO, US-Cotton (21.5), Report of the Appellate Body (20 June 2008) WT/DS267/AB/RW, fn 494. This applies also to the specific remedies in Articles 4 and 7 of the Agreement on Subsidies and Countervailing Measures. See ibid, paras 236-249, especially fn 493 .

86 WTO, Guatemala-Cement I, Report of the Panel (25 November 1998) WT/DS6o/R, para 8.6 (finding that revoking an anti-dumping measure was 'the only appropriate 
concluded that, since WTO Members are allowed a reasonable period of time to comply with reports, 'the WTO-inconsistency has to cease by the end of the reasonable period of time with prospective effect' ${ }^{\prime 8}$ In US-Zeroing (Japan) (Article 21.5-Japan), the Appellate Body further explained that 'the reasonable period of time allows a Member sufficient time to bring itself into conformity with its WTO obligations without being required to provide compensation or being subject to the suspension of concessions or other obligations' ${ }^{88}$

The import of prospective remedies from the trade framework into the investment framework has a certain appeal. Precluding monetary awards prevents the sanctioning of wrongful acts of specific governments from impacting public finances and causing long-lasting damages on the ability of the state to exercise its basic functions. ${ }^{89}$ On the other hand, one may wonder whether a purely prospective remedy is an appropriate response to the kind of measure that is most commonly the subject of investment disputes.

\subsection{CIFA Remedy Provisions and General International Law}

Prospective remedies are arguably well-suited to WTO disputes, which tend to involve policies affecting entire industries and economic sectors rather than violations that affect a specific economic agent. Disputes brought before investor-state arbitral tribunals, on the other hand, tend to concern individual claims of injury, loss of an investment or nullification of an investment.

This is related to the different concrete situations of an exporter and of an investor. A producer in state A that faces an unlawful trade barrier in state B may be satisfied to see the unlawful barrier withdrawn, and to increase its sales

means' of bringing the measure into conformity); WTO, Australia-Automotive Leather II (Article 21.5 - US), Report of the Panel (11 February 2000) WT/DS126/RW, para 6.48 (finding that, in light of the characteristics of the case and the specific provisions regarding remedies in the Agreement on Subsidies and Countervailing Measures, 'repayment in full of the prohibited subsidy is necessary in order to withdraw the subsidy').

87 WTO, US-Zeroing (EC) (Article 21.5 - EC), Report of the Appellate Body (14 May 2009) WT/ DS294/AB/RW, para 299.

88 ibid. See also WTO, US-Zeroing (Japan) (Article 21.5 - Japan), Report of the Appellate Body (31 August 2009) WT/DS322/AB/RW, para 167 ('the DSU requires cessation of all WTO-inconsistent conduct either immediately upon adoption of the DSB's recommendations and rulings or no later than upon expiration of the reasonable period of time').

89 This concern was expressed by the Eritrea-Ethiopia Claims Commission, Final Award Ethiopia's Damages Claims (2009) 26 RIAA 631, 728 ('The size of the Parties' claims raised potentially serious questions involving the intersection of the law of State responsibility with fundamental human rights norms'). 
to state B. Although the producer will have lost profits (due to less volume of sales, lower prices, or both) for the period of time the inconsistent conduct lasted, it is not unreasonable to consider that this producer will attach significant value to the prospect of future sales.

By contrast, a breach of an investment agreement often involves the expropriation of an investment, unlawfully or without adequate compensation, or measures that result in the loss, de jure or de facto, of the value of the investment. An investor from state A who loses its investment in state B due to a law that expropriates all foreign investments in a certain field - or its investment in particular - may find little advantage in obtaining, at the end of the arbitration procedure, a revocation of that law that operates solely for the future.

If the compliance obligation in CIFAs is interpreted like its equivalent in WTO law, an award finding a violation would only entail an obligation for an offender to bring itself into conformity and cease its CIFA-inconsistent conduct with prospective effect. The state found in breach would be able to fully comply with the award by revoking the relevant measure ex nunc (in the case of a breach that is not a policy but an act, it could simply not repeat the act). The legal situations and transfers of property generated by the measure would be fully preserved.

This interpretation would produce three effects. First, it would nullify a number of substantive provisions in CIFAs, making expropriation without compensation de facto permissible when carried out through a one-time measure whose effects could later on be considered as crystallized in the past. Second, it could generate a perverse incentive for governments attempting to extract rent from foreign investors: whereas a measure that aims to extract rent over time (e.g., higher taxes) is subject to a CIFA remedy, a one-time taking would be protected from remedies. Third, this interpretation would make CIFA arbitration unattractive compared to other forms of protection of investment.

Competition from other forms of dispute resolution is particularly significant. If CIFA tribunals are only empowered to award limited remedies and a different international tribunal has jurisdiction over the dispute (which is the case for the ICJ between some CIFA parties), ${ }^{90}$ an investor would probably find it more attractive to convince its home state to take the dispute to the adjudicator from which it can get an effective remedy - compensation or

9o Under the Pact of Bogotá, states accept the jurisdiction of the ICJ between themselves. The Pact applies between Chile and Brazil, Mexico and Brazil, and Peru and Brazil (American Treaty on Pacific Settlement (Pact of Bogota), zo UNTS 55 (1948), art XXXI). 
retrospective restitution - rather than to CIFA arbitration. Alternatively, investors may prefer to make sure they are more effectively protected by contractual arbitration. The usual confidentiality of contractual arbitration would mean that arbitral tribunals could still be established and award compensation, without the transparency that usually accompanies state-to-state arbitrations, and that is increasingly required in investor-state arbitration. ${ }^{91}$

\subsection{Making Compliance Remedies Work for Investment: 'Retrospective Compliance'}

The potential inadequacy of using a WTO-like interpretation for remedies in the investment context may lead CIFA tribunals to adopt the same interpretation as some early WTO panels, pursuant to which full compliance requires not only prospective withdrawal or modification of an unlawful measure (compliance ex nunc) but also retrospective offsetting of the injury caused by the measure (compliance ex tunc). ${ }^{92}$ This could be done by undoing unlawful acts, transferring back property or rights unlawfully expropriated, or providing monetary compensation for the corresponding injury.

Read in this light, the provisions in the Brazil-Mexico and Brazil-Colombia CIFAs requiring agreement of the parties for compensation do not affect the duty of reparation, which arises by the mere fact of the violation. Rather, these provisions ensure the primacy in practice of the remedy of restitution over that of compensation. Whereas restitution has generally been affirmed by courts and arbitral tribunals as the primary remedy for violations, adjudicators often affirm this in principle, only to conclude that restitution is impracticable or undesirable and award compensation (i.e. damages). ${ }^{93}$ In arbitration taking place under these CIFAs, only the parties - i.e., the states parties - are able to decide that the remedy of restitution is undesirable and that compensation is the appropriate remedy. In other cases, tribunals that decide to apply the rule

91 See UNCITRAL Rules on Transparency in Treaty-based Investor-State Arbitration (effective date: 1 April 2014), Resolution adopted by the General Assembly on 16 December 2013 (A/68/PV.68). See also Rules of Procedure for Arbitration Proceedings of ICSID, Rule $48(4)$.

$92 \quad$ See supra $\mathrm{n} 83$.

93 Factory at Chorzów (Merits) (n 78) 46-48. As noted by the arbitrator in BP v Libya, in the vast majority of cases 'the concept of restitutio in integrum has been employed merely as a vehicle for establishing the amount of damages' (BP v Libya (1973) 53 ILR 297, 347). 
of general international law may determine that compensation is owed, and even establish its amount. ${ }^{94}$

Even in the absence of such strict provisions, some investment arbitrators have interpreted the primacy of restitution to mean that compensation should be a subsidiary remedy. In Texaco $v$ Libya, the arbitral tribunal ordered Libya to restore to the claimant its oil operations, holding that restitution was 'the normal sanction for non-performance of contractual obligations ... inapplicable only to the extent that restoration of the status quo ante is impossible. ${ }^{95}$ In Goetz v Burundi, an ICSID arbitral tribunal held that Burundi could award the claimants an 'adequate and effective indemnity', or it could provide them with restitutio in integrum. ${ }^{96}$ In Arif v Moldova, the ICSID arbitral tribunal ordered Moldova, at Moldova's request, 'to enable Claimant to open and operate his duty free store at Chisinau International Airport without undue interruption, ${ }^{97}$

In all of these cases, however, the arbitral tribunals made sure to establish a compensation-based enforcement mechanism as an alternative in case the offending state did not restore the claimant's rights. Under the Brazil-Colombia and Brazil-Mexico CIFAs, on the other hand, tribunals seem to have their hands tied in this regard. The decision to provide compensation as an alternative to restitution depends on the acceptability of the monetary remedy both to the wrongdoer and to the claimant state. While it is not impossible for ex post agreements allowing compensation to become commonplace, an offending state may prefer to hold its ground, and modify its conduct only marginally, rather than agree to provide compensation. Under a strict interpretation of their mandates, tribunals acting under the Brazil-Colombia and Brazil-Mexico CIFAs may not even have the power to calculate damages that would be owed in case the parties did agree to monetary remedies. ${ }^{98}$

94 When the ICJ finds that compensation is due, it usually makes this determination in the abstract, allowing the parties the opportunity to determine for themselves the relevant amount. See Ahmadou Sadio Diallo (Republic of Guinea $v$ Democratic Republic of the Congo), Judgment (30 November 2010) ICJ Reports 2010, 639, 693.

95 Texaco Overseas Petroleum Company and California Asiatic Oil Company v Government of the Libyan Arab Republic, Award on the Merits (19 January 1977) (1979) 53 ILR 389, 507-508.

96 Antoine Goetz and Others v Republic of Burundi, ICSID Case No ARB/95/3, Award (First Part) (2 September 1998) para 130-132.

97 Mr Franck Charles Arif v Republic of Moldova, ICSID Case No ARB/11/23, Award (8 April 2013), para 566 .

98 This is a power held by NAFTA Chapter 20 Panels, empowered to determine 'the degree of adverse trade effects on a party of any measure found not to conform with the 
CIFAs do not constitute the sole attempts to react to perceived overreach of ISDS. In a shift marked by the signing and subsequent revision of the USSouth Korea FTA, ${ }^{99}$ BITs and FTAs increasingly specify that states retain broad regulatory space and limit the possibilities for investment claims. Additionally, many IIAs contain chapters that constrain uses of regulatory power that are deemed undesirable, preventing governments from adopting lax labour and environmental standards in order to attract investment. In most cases, such provisions still lack the enforceability and precision of other more established obligations traditionally found in IIAs, although CPTPP, for example, provides for the possibility of (state-to-state) dispute settlement concerning these obligations. Overall, the notion that the design of IIAs can be a significant element in ensuring that investment serves to generate economic growth, and attain socially desirable objectives in other areas, has gathered support in capitalexporting countries, which were traditionally averse to imposing constraints on investors. ${ }^{100}$

Among the mega-regional agreements, the CPTPP's approach to ISDS is traditional. It sets forth an investment arbitration mechanism, ${ }^{101}$ whose most noteworthy point is perhaps a specific exception for tobacco-related measures (the 'tobacco carve-out'), precluding ISDS challenges to public policy measures relating to the production or commercialization of tobacco products. ${ }^{102}$ Additionally, the CPTPP precludes the weakening of labour and environmental standards to attract investment. The Labour chapter expressly recognizes the parties' commitment to observing their obligations as International Labour Organization members, prohibits the adoption of labour standards for protectionist purposes, and precludes the use of waivers or derogations from labour rights to attract trade or investment. ${ }^{103}$ The Environment chapter

obligations of the Agreement or to have caused nullification or impairment' (NAFTA, art 2008).

99 Free Trade Agreement Between the United States of America and the Republic of Korea (signed 30 June 2007, modified 5 December 2010) <https://ustr.gov/trade-agreements/ free-trade-agreements/korus-fta/final-text> accessed 6 March 2016.

100 This trend is not without its critics. See supra $\mathrm{n} 35$.

101 CPTPP, art 9.19.

102 СРТPP, art 29.5. See also СРТPP, art 9.3 and ch 11, which read together jointly establish a carve-out for the regulation of financial markets.

103 СРТPP, art 19.2. 
recognizes the right of states to determine their level of protection and prohibits the weakening of environmental protection to encourage trade or investment. 104

Bolder attempts at reform have come from the proposals put forward by India and the EU to address some of the shortcomings found in the current investment regime, aiming to create arrangements that respond to some of their constituencies' demands and concerns. Table 1 below compares CIFA provisions to the solutions proposed by India and the EU for the same issues (we leave CPTPP out, given its more traditional ISDS provisions).

The EU's proposals come following a public consultation launched by the European Commission on whether ISDS should be embodied in the TTIP, which drew over 150,000 replies. ${ }^{105}$ In its draft TTIP investment chapter, the EU proposes a full-fledged judicial system, featuring a Tribunal of First Instance ${ }^{106}$ and appellate review by a 'permanent Appeal Tribunal. ${ }^{107}$ Besides the permanent Tribunals established on a bilateral basis, the EU proposal foresees the creation of a 'multilateral investment tribunal' or 'multilateral appellate mechanism, ${ }^{108}$ a medium-term goal that follows failed past attempts at establishing such a mechanism. ${ }^{109}$

This system with permanent adjudicators is already contemplated in Chapter 8 of the EU-Vietnam FTA, including a nine-member Tribunal to hear investors' claims, a six-member 'permanent Appeal Tribunal' and the provision for a future 'multilateral appellate mechanism. ${ }^{110}$ As discussed above, this system was also incorporated into the revised CETA, which now establishes a fifteen-member Tribunal ${ }^{111}$ and an Appellate Tribunal that can uphold, modify or reverse awards of the Tribunal. ${ }^{112}$ Pursuant to CETA Article 8.29, the

\footnotetext{
104 CPTPP, art 20.3.

105 European Commission, 'Online Public Consultation on Investment Protection and Investor-to-State Dispute Settlement (ISDS) in the Transatlantic Trade and Investment Partnership Agreement: Report' (15 January 2015) <http://trade.ec.europa.eu/doclib/ docs/2015/january/tradoc_153044.pdf> accessed 6 March 2016.

106 TTIP EU Proposal, ch II, s 3(1), art 9.

107 ibid art 10(1).

108 ibid art 12.

109 Jürgen Kurtz, 'NGOs, the Internet and International Economic Policy Making: The Failure of the OECD Multilateral Agreement on Investment' (2002) 3 Melbourne JIL 213.

110 EU-Vietnam Free Trade Agreement, Chapter 8: Investments <http://trade.ec.europa.eu/ doclib/docs/2016/february/tradoc_154210.pdf $>$ accessed 31 January 2018.

111 CETA, art 8.27.

112 ibid art 8.28.
} 
parties will pursue the establishment of a multilateral investment tribunal. ${ }^{113}$ The modifications to CETA agreed to in early 2016 also aimed at ensuring that the text of the treaty explicitly recognizes the right of the parties to exercise their regulatory power for legitimate public objectives. ${ }^{114}$ If the United States adheres to this institutional design in concluding TTIP with the EU, this will be a game-changer in international investment governance. A multilateral tribunal would likely bring as profound an impact on the investment regime as the WTO Appellate Body has brought to the international trade regime. ${ }^{115}$

Responding to similar concerns, India recently published an updated version of its Model BIT, including some noteworthy features. Article 15 reinstates the exhaustion of local remedies rule usually set aside in ISDS, requiring aggrieved investors to resort to domestic courts or administrative instances before presenting a claim. Additionally, the investor must present its domestic claim within 1 year of the date it knows (or should have known) of the adoption of the relevant measure. The India Model BIT also proposes rules and principles to 'recalibrate' international investment law, aiming to strike a balance between host state regulatory space and protection for foreign investors. In the perhaps most striking part, it excludes from the scope of application of the BIT measures of local governments, as well as measures relating to taxation, compulsory licenses in intellectual property, government procurement, and subsidies. 116

Significantly, Article 29 of the India Model BIT also foresees the possible establishment of an 'Appeals Facility ... to provide coherence to the interpretation of provisions of th $[\mathrm{e}]$ treaty'. A footnote specifies that this 'appellate body or similar mechanism ... may include an appellate mechanism for reviewing investor-state disputes established under a separate multilateral agreement in future. This is coupled with a more restrictive definition of what can be characterized as an investment and alterations to the scope of standards of protection contained in its previous IIAs. Thus, India's new approach departs from traditional IIAs not only as regards dispute settlement but also with respect to

\footnotetext{
113 See also European Commission, 'Joint Statement: Canada-EU Comprehensive Economic and Trade Agreement (CETA)' (29 February 2016).

114 CETA, art 8.9, with an equivalent provision also found on the EU-Vietnam Free Trade Agreement, art 13 .

115 At the time of writing, the sole information available on the position of the United States was an informal rejection of the idea of a permanent institution to adjudicate investment claims. Euractiv, 'US Rejects EU Proposal for Investment Court, Insists on Retaining ISDS' <www.euractiv.com/section/trade-society/news/us-rejects-eu-proposal -for-investment-court-insists-on-retaining-isds/> accessed 31 January 2018.

116 India Model BIT, art 2.6.
} 
substantive rules. It has been reported that this new treaty template will serve as the starting point of a thorough renegotiation process to be undertaken by India of its existing IIAs. ${ }^{17}$

TABLE 1 New international investment agreements: a comparison

Brazil CIFAs
India Model BIT

\section{EU models: CETA and \\ EU-Vietnam FTA}

117 'India to Rework Investment Treaties with All Partners' (The Hindu Business Line, 30 June 2016) < www.thehindubusinessline.com/economy/policy/india-to-rework-investment -treaties-with-all-partners/article8793125.ece> accessed 14 February 2018. 
TABLE $1 \quad$ New international investment agreements (cont.)

\begin{tabular}{|c|c|c|c|}
\hline & Brazil CIFAs & India Model BIT & $\begin{array}{l}\text { EU models: CETA and } \\
\text { EU-Vietnam FTA }\end{array}$ \\
\hline $\begin{array}{l}\text { Restrictions } \\
\text { on protected } \\
\text { investor }\end{array}$ & $\begin{array}{l}\text { Definition of Investor: a } \\
\text { person (legal or natural) } \\
\text { or an autonomous } \\
\text { set of assets (Brazil- } \\
\text { Mozambique CIFA, } \\
\text { art } 3.2 \text { ) } \\
\text { - Legal person has to have } \\
\text { the center of economic } \\
\text { activities in the terri- } \\
\text { tory of a Party (Brazil- } \\
\text { Mozambique CIFA, art } \\
\text { 3.2) }\end{array}$ & $\begin{array}{l}\text { - Natural or legal person } \\
\text { 'conducting real and } \\
\text { substantial business } \\
\text { operations in the Home } \\
\text { State' }(\operatorname{art} 1.9(\mathrm{i})) \\
\text { - Restriction on } \\
\text { dual-nationals to sue: } \\
\text { test of 'dominant or } \\
\text { effective nationality' } \\
\text { (art 1.12) }\end{array}$ & $\begin{array}{l}\text { Covers prospective } \\
\text { investors: investor is ‘a } \\
\text { natural person or a ju- } \\
\text { ridical person of a Party } \\
\text { that seeks to make, is } \\
\text { making or has already } \\
\text { made an investment in } \\
\text { the territory of the other } \\
\text { Party' (EU-Vietnam } \\
\text { FTA, ch I, General } \\
\text { Provisions - (q) }\end{array}$ \\
\hline $\begin{array}{l}\text { Carve-out for } \\
\text { regulatory } \\
\text { space of host } \\
\text { country }\end{array}$ & & $\begin{array}{l}\text { Reaffirmed in the } \\
\text { preamble: 'right of } \\
\text { parties to regulate invest- } \\
\text { ments in their territory in } \\
\text { accordance with their law } \\
\text { and policy objectives includ- } \\
\text { ing the right to change the } \\
\text { conditions applicable to } \\
\text { such investments' (preamble, } \\
\text { third recital) } \\
\text { General exceptions similar } \\
\text { to WTO (art 16) } \\
\text { Measures by local govern- } \\
\text { ments excluded from the } \\
\text { scope of the treaty } \\
\text { (art } 16.3 \text { ) }\end{array}$ & $\begin{array}{l}\text { Right of parties to regu- } \\
\text { late through measures } \\
\text { necessary to achieve } \\
\text { legitimate policy objec- } \\
\text { tives (CETA, art 8.9; } \\
\text { EU Vietnam FTA, } \\
\text { art } 13 \text { bis) } \\
\text { - Detailed provisions on } \\
\text { the scope of this right: } \\
\text { no commitment from } \\
\text { a Party not to change } \\
\text { its legal and regulatory } \\
\text { framework in a manner } \\
\text { that might negatively } \\
\text { impact the investment/ } \\
\text { investor (art 13bis) }\end{array}$ \\
\hline
\end{tabular}


Brazil CIFAs
India Model BIT
EU models: CETA and

EU-Vietnam FTA

\begin{tabular}{|c|c|c|c|c|}
\hline $\begin{array}{l}\text { Investor } \\
\text { obligations } \\
\text { and/or cor- } \\
\text { porate social } \\
\text { responsibility } \\
\text { (CSR) efforts }\end{array}$ & $\begin{array}{l}\text { Best endeavors obliga- } \\
\text { tions to follow general } \\
\text { guidelines and stan- } \\
\text { dards of CSR practices } \\
\text { (Brazil-Mozambique } \\
\text { CIFA, Brazil-Angola } \\
\text { CIFA, Annex II; } \\
\text { Brazil-Colombia CIFA, } \\
\text { art 13; Brazil-Mexico } \\
\text { CIFA, art 13; Brazil- } \\
\text { Peru CIFA, } \\
\text { art 2.13(2)) }\end{array}$ & & $\begin{array}{l}\text { Compliance with host state } \\
\text { laws, including, among } \\
\text { others: 'information shar- } \\
\text { ing requirements concern- } \\
\text { ing the Investment, laws } \\
\text { relating to Human rights, } \\
\text { consumer protection and } \\
\text { fair competition, relevant } \\
\text { national and internation- } \\
\text { ally accepted standards of } \\
\text { corporate governance and } \\
\text { accounting practices' } \\
\text { (art 12) } \\
\text { Best endeavours obligation: } \\
\text { 'strive to contribute to the } \\
\text { development objectives' } \\
\text { (art 12.2) } \\
\text { Observance of '[r]ights, } \\
\text { traditions and customs } \\
\text { of local communities and } \\
\text { indigenous peoples of the } \\
\text { Host State' (art } 12.2 \text { ) } \\
\text { CSR: 'shall endeavour to } \\
\text { voluntarily incorporate } \\
\text { internationally recognized } \\
\text { standards of corporate } \\
\text { social responsibility' } \\
\text { (art } 12 \text { ) }\end{array}$ & $\begin{array}{l}\text { - Parties agree to } \\
\text { 'enhanced coopera- } \\
\text { tion' on some areas of } \\
\text { corporate social } \\
\text { responsibility (CETA, } \\
\text { art } 24.12 \text {, Cooperation } \\
\text { on environment issues, } \\
\text { art 25.4) } \\
\text { - Contained in the pre- } \\
\text { amble of the agreement } \\
\text { (CETA, Preamble) } \\
\text { - Not applicable in the } \\
\text { EU-Vietnam FTA }\end{array}$ \\
\hline
\end{tabular}


TABLE $1 \quad$ New international investment agreements (cont.)

\begin{tabular}{|c|c|c|c|}
\hline & Brazil CIFAs & India Model BIT & $\begin{array}{l}\text { EU models: CETA and } \\
\text { EU-Vietnam FTA }\end{array}$ \\
\hline $\begin{array}{l}\text { Treatment } \\
\text { obligations }\end{array}$ & $\begin{array}{l}\text { National treatment ob- } \\
\text { ligation and prohibition } \\
\text { of nationality-based } \\
\text { discrimination (Brazil- } \\
\text { Colombia CIFA, art 5.1) } \\
\text { - Transparency obliga- } \\
\text { tion, in the publication } \\
\text { of norms and regula- } \\
\text { tions and 'reasonable } \\
\text { opportunity afforded } \\
\text { to interested parties to } \\
\text { pronounce on proposed } \\
\text { measures' (Brazil- } \\
\text { Colombia CIFA, art 8; } \\
\text { Brazil-Angola CIFA, } \\
\text { art 13) } \\
\text { Does not provide for } \\
\text { FET }\end{array}$ & $\begin{array}{l}\text { Transparency obligation } \\
\text { (art 1o) } \\
\text { Does not provide for FET as } \\
\text { an independent standard } \\
\text { but adopts a benchmark } \\
\text { more aligned with customary } \\
\text { international law, providing } \\
\text { protection against 'denial } \\
\text { of justice, un-remedied and } \\
\text { egregious violations of } \\
\text { due process, or manifestly } \\
\text { abusive treatment involv- } \\
\text { ing continuous, unjustified } \\
\text { and outrageous coercion or } \\
\text { harassment' - prescribing } \\
\text { the types of conduct inves- } \\
\text { tors are protected from and } \\
\text { not explicitly providing for } \\
\text { the protection of investor's } \\
\text { legitimate expectations } \\
\text { (art 3.(i) through (iii)) } \\
\text { National treatment: viola- } \\
\text { tions are necessarily nation- } \\
\text { ality-based and limited to } \\
\text { circumstances where there } \\
\text { is 'intentional and unlawful } \\
\text { discrimination' (art } 4.2 \text { ) } \\
\text { Absence of MFN clause }\end{array}$ & $\begin{array}{l}\text { Fair and equitable } \\
\text { treatment and full } \\
\text { protection and security } \\
\text { standards (CETA, art } \\
\text { 8.10; EU-Vietnam FTA, } \\
\text { art 14) } \\
\text { - Detailed provisions on } \\
\text { the scope of the obliga- } \\
\text { tions: full protection is } \\
\text { restricted to 'physical } \\
\text { security' of investments } \\
\text { and investors (CETA, } \\
\text { art 8.1o(5), EU-Vietnam } \\
\text { FTA, art14.2) } \\
\text { Detailed provisions on } \\
\text { fair and equitable treat- } \\
\text { ment obligation: 'denial } \\
\text { of justice', fundamental } \\
\text { breach of due process, } \\
\text { manifest arbitrariness, } \\
\text { targeted discrimination, } \\
\text { or abusive treatment } \\
\text { (CETA, art 8.1o(2), } \\
\text { EU-Vietnam FTA, } \\
\text { art } 14 \text { ) } \\
\text { Dynamic nature of } \\
\text { FET: 'The Parties shall, } \\
\text { upon request of a Party, } \\
\text { review the content } \\
\text { of the obligation to } \\
\text { provide fair and } \\
\text { equitable treatment' } \\
\text { (CETA, art 8.1o(3)) }\end{array}$ \\
\hline
\end{tabular}




\section{Brazil CIFAs India Model BIT EU models: CETA and}

EU-Vietnam FTA

\begin{tabular}{|c|c|c|c|c|}
\hline $\begin{array}{l}\text { Features } \\
\text { of dispute } \\
\text { settlement } \\
\text { system }\end{array}$ & - & $\begin{array}{l}\text { Ombudsman and focal } \\
\text { points to act for the pre- } \\
\text { vention and avoidance } \\
\text { of disputes (Brazil- } \\
\text { Mozambique CIFA, } \\
\text { art 15) } \\
\text { Negotiations and } \\
\text { consultations preceding } \\
\text { the establishment of } \\
\text { arbitral proceedings } \\
\text { (Brazil-Mozambique } \\
\text { CIFA, art. 15.2) } \\
\text { Consultations with } \\
\text { the Joint Committee } \\
\text { (Brazil-Mexico CIFA, } \\
\text { art 18; Brazil-Colombia } \\
\text { CIFA, art 22) } \\
\text { Arbitral proceedings in } \\
\text { Latin American CIFAs: } \\
\text { State-to-state (Brazil } \\
\text { Mexico CIFA, art 19; } \\
\text { Brazil Colombia CIFA, } \\
\text { art 23) }\end{array}$ & $\begin{array}{l}\text { - ISDS under ICSID } \\
\text { or UNCITRAL rules } \\
\text { (art 16) } \\
\text { - Exhaustion of local } \\
\text { remedies (art 14.3) } \\
\text { - Statute of limitations: } 1 \text { year } \\
\text { to challenge a measure } \\
\text { (art 14.3(i)) } \\
\text { - State-to-state dispute } \\
\text { settlement (art 30), } \\
\text { consultations to be followed } \\
\text { by an arbitration } \\
\text { (arts 14 and 15) } \\
\text { Requirements for the } \\
\text { selection of arbitrators and } \\
\text { transparency requirements; } \\
\text { standard arbitrator chal- } \\
\text { lenges: 'justifiable doubts' } \\
\text { (art 14.6(i) through (iii) } \\
\text { Possible appeals mechanism } \\
\text { to be designed by the Parties } \\
\text { (art 29) }\end{array}$ & 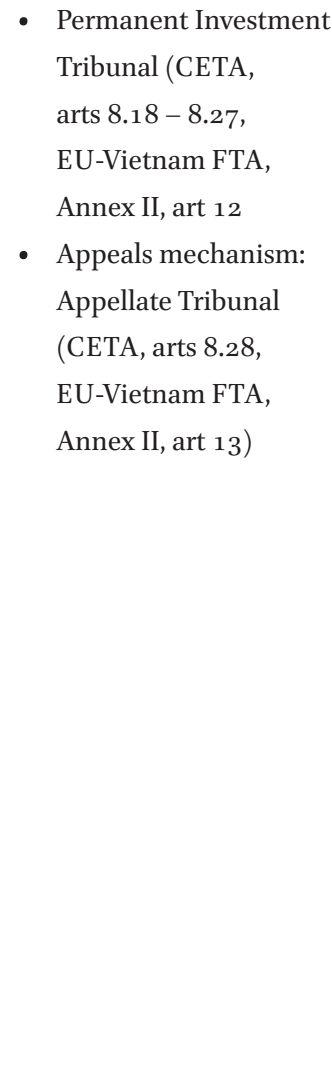 \\
\hline
\end{tabular}

\subsection{CIFA Mechanism of Dispute Settlement: An Alternative for the Future?}

Contrasting with other proposals discussed above, the requirement in CIFAs to resort to state-to-state dispute settlement could be seen as a potential obstacle to investors seeking redress for unlawful treatment. State-to-state litigation may be perceived as a contentious act, marring relations between the disputing parties across the board. On the other hand, state-to-state claims for breaches that affect private interests are often brought before 
international adjudicators. This includes instances of claims before ad hoc arbitrators ${ }^{118}$ and the ICJ. ${ }^{119}$ More significantly, two adjudication systems have been successful in normalizing states' resort to litigation to protect their nationals: one is the WTO dispute settlement system and the other is the adjudication system of UNCLOS.

\subsubsection{WTO Dispute Settlement}

Since its inception in 1995 and until the end of 2015, the WTO dispute settlement system had received 501 requests for consultations. On average, therefore, WTO members have formally resorted to the system almost 24 times a year. Resort to WTO dispute settlement has led to 159 adopted panel reports, 104 of which were adopted after review by the Appellate Body, which may uphold, modify or reverse legal findings and conclusions of panels. This makes the WTO dispute settlement the most used of all state-to-state dispute settlement mechanisms.

Equally importantly, the WTO dispute settlement system is used by developed and developing countries alike. Both Brazil and the CIFA parties whose treaties include dispute settlement clauses have significant experience resorting to WTO adjudication. Brazil has been a complainant in 29 disputes and a respondent in 16; Mexico has been a complainant in 23 disputes and a respondent in 14; Chile has been a complainant in 10 disputes and a respondent in 13; Colombia has been a complainant in 5 disputes and a respondent in 5; and Peru has been a complainant in 3 disputes and a respondent in 5 . And, whereas Brazil's complaints traditionally targeted developed countries, its most recent consultations requests targeted Indonesia, ${ }^{120}$ South Africa ${ }^{121}$ and Thailand. ${ }^{122}$

118 Italy v Cuba, Final Award (15 January 2008) <www.italaw.com/cases/580> accessed 31 January 2018; States have also, generally unsuccessfully, started arbitral proceedings to try to stop ISDS proceedings. See Anthea Roberts, 'State-to-State Investment Treaty Arbitration: A Hybrid Theory of Interdependent Rights and Shared Interpretative Authority' (2014) 55 Harvard Intl L J 1.

119 Ahmadou Sadio Diallo (n 94) 639.

120 WTO, Indonesia-Measures Concerning the Importation of Chicken Meat and Chicken Products (DS484), consultations requested on 16 October 2014; WTO, Indonesia-Measures Concerning the Importation of Bovine Meat (DS506), consultations requested on 4 April 2016.

121 WTO, South Africa-Anti-Dumping Duties on Frozen Meat of Fowls from Brazil (DS439), consultations requested on 21 June 2012.

122 WTO, Thailand-Subsidies Concerning Sugar ( $\mathrm{DS}_{507}$ ), consultations requested on 4 April 2016. 
This is relevant both because it demonstrates that CIFA parties have resorted to international adjudication to defend economic interests of their nationals and because engaging in WTO litigation has required developing countries to build up institutions within which the public sector and the private sector can cooperate. ${ }^{123}$ Once this institutional structure is in place, it becomes more likely that governments will be aware of issues of concern to their local industries, and that industries will become aware of the possibilities available for them to request governments to defend their industries' interests through international adjudication.

Thus, this increased communication provides the incentives and the information required for governments to bring claims to adjudication. As regards Brazil, participation in WTO litigation led to the formation of important public-private partnerships for dispute settlement, ${ }^{124}$ allowing it to successfully challenge a number of measures before WTO adjudicators, most significantly in the area of subsidies. ${ }^{125}$ Other CIFA parties are active in WTO dispute settlement as well, and this experience may prove essential in preparing them to actually resort to CIFA litigation to seek redress for violations.

\subsubsection{UNCLOS Prompt Release: Flag States and Private Litigation}

Another basis for state-to-state dispute settlement regularly employed to settle disputes involving primarily private interests is the UNCLOS. Over $80 \%$ of the 24 disputes taken to ITLOS concern the unlawful detention of vessels, with 15 cases $(62 \%)$ having been brought under the special procedure under UNCLOS Article 292 for prompt release of unlawfully detained vessels. In addition to these, three non-prompt release cases featured, as requests for provisional measures, requests for the prompt release of ships and crew, ${ }^{126}$ and

123 See Gregory Shaffer and Ricardo Meléndez-Ortiz (eds), Dispute Settlement in the WTO: The Developing Country Experience (CUP 2010).

124 Gregory Shaffer, Michelle Ratton Sanchez and Barbara Rosenberg, 'The Trials of Winning at the WTO: What Lies Behind Brazil's Success' (2008) 41 Cornell ILJ 383, 392.

125 See WTO, Canada-Measures Affecting the Export of Civilian Aircraft (DS70), consultations requested on 14 March 1997; WTO, Canada-Export Credits and Loan Guarantees for Regional Aircraft, Report of the Panel (28 January 2002) WT/DS222/R; WTO, United States-Subsidies on Upland Cotton, Report of the Appellate Body (3 March 2005) WT/

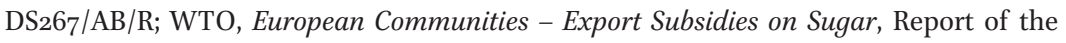
Appellate Body (28 April 2005) WT/DS265/AB/R; WT/DS266/AB/R; WT/DS283/AB/R; Canada-Measures Concerning Trade in Commercial Aircraft (DS522), consultations requested on 8 February 2017.

126 "ARA Libertad" (Argentina v Ghana), Provisional Measures, Order (15 December 2012) ITLOS Reports 2012, 332; "Arctic Sunrise" (Kingdom of the Netherlands v Russian 
in two cases states requested compensation for unlawful detention of ships bearing their flag. ${ }^{127}$

An interesting aspect of the prompt release procedure established by UNCLOS Article 292 is that applications made under this provision may be made 'by or on behalf of the flag State of the vessel' (emphasis added). This wording has generated a sui generis litigation, done entirely by private lawyers, paid by and responding primarily to ship-owners, but formally representing the flag state of the vessel. In the 'Volga' case, Judge ad hoc Shearer noted the existence of a number of 'cases before the Tribunal [in which], although the flag State has been represented by a State agent, the main burden of presentation of the case has been borne by private lawyers retained by the vessel's owners.' ${ }^{128}$ In other cases, such as the 'Louisa'129 or the 'Juno Trader', 130 the flag state is known to provide flags of convenience. ITLOS has also acted to prevent what it perceived as abuse of these provisions. In 'Grand Prince', the purported flag state had de-registered the vessel, and the Tribunal concluded that, as a result, the ship-owner was not entitled to resort to the UNCLOS prompt release procedure 'on behalf of' Belize. ${ }^{131}$

The amount of cases brought under UNCLOS dispute settlement is significantly lower than the number of WTO disputes. Litigation under UNCLOS nonetheless follows the same principle, with states regularly taking up cases to protect economic interests of their nationals. In fact, in UNCLOS dispute settlement states have given their nationals far more control over adjudication than in WTO dispute settlement, allowing lawyers employed by their nationals to represent their clients' interests and plead directly before international

Federation), Provisional Measures, Order (22 November 2013) ITLOS Reports 2013, 230; "Enrica Lexie" Incident (Italyv India), Provisional Measures, Order (24 August 2015) ITLOS Reports 2015, 182.

127 M/V"SAIGA" (No 2) (n 78) 1357; M/V “Louisa" (Saint Vincent and the Grenadines v Kingdom of Spain), Judgment (23 May 2013) ITLOS Reports 2013, 4; $M / V$ "Virginia G" (Panama/ Guinea-Bissau), Judgment (14 April 2014) ITLOS Reports 2014, 4. Besides these cases, there are cases referred directly to PCA arbitral tribunals under UNCLOS.

128 "Volga" (Russian Federation v Australia), Prompt Release, Judgment (2 December 2002), Dissenting Opinion of Judge ad hoc Shearer, ITLOS Reports 2002, 66, 72. See Saiful Karim, 'Conflicts over Protection of Marine Living Resources: The "Volga Case" Revisited' (2011) 3 Goettingen JIL 101-127.

$129 M / V$ "Louisa" (n 127) 4.

130 "Juno Trader" (Saint Vincent and the Grenadines v Guinea-Bissau), Prompt Release, Judgment (18 December 2004) ITLOS Reports 2004, 17.

131 "Grand Prince" (Belize v France), Prompt Release, Judgment (20 April 2001) ITLOS Reports 2001,17 . 
adjudicators. In this regard, UNCLOS dispute settlement also presents a potential model for states and investors considering resort to CIFA state-to-state dispute settlement provisions.

One could see CIFAs as a possible return to the pre-BITs phase of politicized investment protection. BITs, after all, aim to depoliticize investment disputes, providing investors with an instrument to counter governmental power while permitting the non-involvement of the government of the home country of the investor. As compared to the EU and Indian proposals, assessments of CIFAs that take as a starting point the desirability of ISDS-style investment protection will inevitably lead to disappointment.

On the other hand, BITs have arguably focused too much on investors' rights, to the detriment of the rights of host states to regulate their economy and establish limits to investors' conduct. Those who consider that BITs have imposed overly strict restrictions on states and failed to impose obligations on investors will welcome the lack of ISDS as a means of enforcement beyond the control of home governments, and call for a strengthening of the provisions establishing obligations for investors. ${ }^{132}$

The absence of ISDS in CIFAs does not, in and of itself, preclude the development of a significant practice of CIFA litigation. It certainly allows for a degree of political control over disputes by home states. At the same time, one may expect home states to be interested in advancing the economic interests of their nationals. The main issue then becomes whether the system of remedies established under CIFAs, seemingly inspired by WTO law, is adequate to deal with investor's claims. If it is not, CIFA adjudication may not serve the purpose of providing investors with redress, meaning that they will continue to depend on their home government not only to start proceedings but to actually obtain any meaningful redress following a victory on the merits.

Perhaps the best way to understand CIFA adjudication is by examining it in light of its stated goal, that is, to re-establish compliance with the substantive CIFA rules and, as the name of the agreements suggests, facilitate and stimulate cooperation in the field of inter-state investment. The function of CIFA adjudication is different from that fulfilled by ISDS. Rather than providing aggrieved investors with a legal instrument to leave the host country with

132 Bernasconi-Osterwalder and Brauch (n $\left.5^{8}\right)$ 15-16. 
the value of their investment, CIFAs aim to restore the value of the investment and ensure take their projects forward.

An assessment of the influence of this approach over the development of the investment regime must wait for practice to emerge. However, the comparison with initiatives and proposals put forward by others demonstrates that Brazil is not alone in its concerns. And the assessment of existing practice of other dispute settlement regimes demonstrates that, under the right circumstances, state-to-state adjudication provides a useful avenue for private parties to demand compliance with treaty obligations. 